\title{
The dilemma of COVID-19 in dental practice concerning the role of saliva in transmission: a brief review of current evidence
}

From December 12, 2019, a pandemic of acute respiratory syndrome, the novel human coronavirus disease (COVID-19), caused by a novel $\beta$-coronavirus (2019$\mathrm{nCoV}$ ) began to grow globally by person-to-person transmission. The production of airborne material during aerosol generating dental procedures would expose dental team and patients to remarkable risk of transmission concerning the faceto-face communication and splattered saliva, blood, and other body fluids. Dental professionals can be a substantial help in preventing the transmission of COVID-19. This study has reviewed relevant current evidences in literature that has addressed the role of saliva and the threats that may be inherent in transmission of the disease during dental procedures. The study also offers feasible proactive and preventive measures for dental practice during the outbreak to block possible person-toperson or indirect transmission in dental settings.

Keywords: SARS-CoV-2, COVID-19, Saliva, Transmission, Infection Control

\section{Introduction}

The novel coronavirus 2019 (2019-nCoV) or severe acute respiratory syndrome coronavirus 2 (SARS-CoV-2), is an enveloped positive-sense RNA virus which belongs to the Coronaviridae family. This RNA virus seems to be correlated but different from the other coronaviruses causing Severe Acute Respiratory Syndrome (SARS-CoV) and Middle East Respiratory Syndrome (MERS-CoV) (1,2). From December 12, 2019, a pandemic of acute respiratory syndrome, the novel human coronavirus disease (COVID-19), began to grow among humans by person-to-person transmission $(3,4)$. It is believed that Rhinolophus affinis bat and pangolins are natural and intermediate hosts of the virus, respectively (4). The common clinical symptoms of this infection include fever, cough, fatigue, acute respiratory disease with abnormal chest CT (5); despite these symptoms, COVID-19 mostly presents with mild severity. On the other hand, compared to COVID-19, higher mortality rates were reported for either SARS-CoV (10\%) or MERS-CoV (37\%) (3); however, COVID-19 can be more contagious and spread faster than the other two mentioned respiratory syndromes (6). During this pandemic, dentistry is considered as one of the most high-risk jobs, since dentists are in close contact with patients' oral cavity especially saliva (7). Oral cavity is a main source of spreading respiratory droplets, which contains millions of virus in infected individual. These droplets may involve oral, nasal and ocular mucosa of dental health workers directly or indirectly through contact or contaminated surfaces (8). In spite of some uncertainties about the definite characteristics of SARS-CoV-2, it has recently been reported that this novel virus could be detected in saliva of infected patients (9). It is still not clear if SARS-CoV-2 viruses survive in human saliva and if yes, how long this endurance would be.

\author{
Shahram Hamedani' ${ }^{(D)}$, \\ Nima Farshidfar ${ }^{2} \mathbb{D}$, \\ Ava Ziaei $^{3}$ (D), \\ Hamidreza Pakravan²
}

ORCID IDs of the authors: S.H. 0000-0003-1119-2565; N.F. 0000-0003-2944-5305; A.Z. 0000-0003-4865-0494; H.P. 0000-0001-6987-6738

'Oral and Dental Disease Research Center, School of Dentistry, Shiraz University of Medical Sciences, Shiraz, Iran

${ }^{2}$ Student Research Committee, Shiraz University of Medical Sciences, Shiraz, Iran

${ }^{3}$ Student Research Committee, Faculty of Medicine, Hormozgan University of Medical Sciences, Bandar Abbas, Iran Corresponding Author: Nima Farshidfar E-mail: n.farshidfar@icloud.com Received: 05 May, 2020 Revised: 10 May, 2020 Accepted: 18 May, 2020 DOI: 10.26650/eor.20200050 
Likewise, it is not verified whether SARS-CoV-2 is detectable in human saliva during the early incubation period or not. Evidently, many biomarkers in saliva help early diagnosis of oral cancer. However, it is still unclear if any salivary biomarker could be feasible for early diagnosis of COVID-19. Moreover, there are many established antiviral proteins in the saliva that can be regarded in protection against COVID-19 (9-12). Because of the presence of the virus in the saliva, it might be transmitted directly or indirectly from individuals without apparent respiratory symptoms (9). Since many of dental procedures are spatter- and aerosol-generating, the risk of airborne contamination through droplet nuclei in dental clinics is very high $(6,13)$. Considering all these disputes, health care professionals specially dentists must protect themselves and their patients from the spread of the virus, and subsequently adopt extra-protective measures in order to prevent the transmission of SARS-CoV-2 $(5,6)$. Therefore, concerning the role of saliva in transmission, this brief and rational overview was conducted to find, discuss, and summarize the current relevant evidences to highlight the empirical role of dental practitioners and their staff on prevention and protection of themselves, their patients, and public from this world-spread infection.

\section{Search strategy}

A search was made through electronic databases (Web of Science, MEDLINE, Scopus and Google Scholar) with particular focus on the latest information on World Health Organization (WHO), American Dental Association (ADA), Centers for Disease Control and Prevention (CDC) and United Kingdome National Health Service (UK NHS) websites. The keywords; 'SARS-CoV-2' or 'COVID-19' or '2019-nCoV' and 'Dentistry' or 'Infection Control, Dental' or 'Saliva' were searched in title/ abstract of publications; limited to 2019 to 2020. The inclusion criteria were all articles relevant to dentistry and dental practice published in English. Moreover, the reference lists of the selected papers were reviewed for possible inclusion. Titles and abstracts of all selected papers were reviewed and complete text of the articles has been carefully checked upon confirmation for potential inclusion. To sum up, 39 articles, which demanded qualities to meet our criteria for this review were recited and retrieved.

\section{Transmission}

The transmission of COVID-19 most probably occurs by contact, droplet, and conceivably airborne under particular conditions concerning the previous evidences on SARS-CoV outbreaks.(14) SARS-CoV-2 is transmitted through droplets both directly and indirectly (8). The direct transmission occurs via coughing, sneezing, and droplet inhalation. Whereas, the indirect transmission occurs by touching eye, nose or mouth after contacting a contaminated surface (8).

\section{Mechanism of transmission}

Previous study demonstrated that SARS-CoV-2 show 79\% similarity in nucleotide sequencing to SARS-CoV.(2) In addition, both viruses use the same host receptor named Angiotensin Converting Enzyme 2 (ACE2) receptor to enter cells
(6). Xu et al. (15), in a study showed that ACE2 receptors are being expressed in oral mucosa, especially in tongue tissue which makes the oral cavity more susceptible for SARSCoV-2 infection. In a study on Chinese rhesus macaques, which mimics the human situation, it was demonstrated that their ACE2 ${ }^{+}$epithelial cells lining salivary gland ducts were early targets of SARS-CoV infection (16). Although no study has been done so far, due to similarities in the mechanism of cell entry, it seems SARS-CoV-2 have the potential to infect salivary gland ducts cells (14). Besides, these infected cells may constitute an important source of virus in saliva. Herein, we elucidate various possible transmission routes of SARS-CoV-2 in dental practice.

\section{Routes of transmission}

\section{Droplet and aerosol transmission}

As announced by $\mathrm{WHO}$, transmission primarily occurs by means of respiratory droplets $(>5-10 \mu \mathrm{m})$ within $1 \mathrm{~m}$. Moreover, during aerosol-generating procedures, airborne transmission may be possible through droplet nuclei $(\leq 5 \mu \mathrm{m})$ which can spread over distances exceeding $1 \mathrm{~m}$ (13). Droplets and aerosols of individual's respiratory system spreads around by talking, laughing, singing, coughing and sneezing, by which infected individual can transmit disease (17). Geralton et al. (17) have demonstrated that in an individual with symptomatic respiratory viral infection both droplets and aerosols, which contain viral RNA, are produced by coughing or breathing. However, some studies have reported that asymptomatic individuals might spread the SARS-CoV-2 $(18,19)$. It is recently documented that SARS-CoV-2 could be viable and infectious for hours in aerosols and for days on surfaces which make it feasible to be transmitted through aerosol and fomite (20). Previous study showed that in dental clinics large amounts of droplets and aerosols are produced by particular dental procedures in patients' oral cavity, which are mixed by patients' saliva or even blood. These particles are small enough to stay in the air for an extended period and be transmitted to clinicians directly or settle down on surfaces and be transmitted indirectly (6). Furthermore, To et al. (9) have detected SARS-CoV-2 in saliva of infected individuals by viral culture. Therefore, it seems that during dental procedures, SARS-CoV-2 has the potential to be transmitted via droplets and aerosols of saliva, from symptomatic, presymptomatic, or probably asymptomatic individuals.

\section{Contact and contaminated surfaces transmission}

WHO declared that SARS-CoV-2 could be transmitted through droplets, large particles that settle down on surfaces in short periods of time (8). Previous studies have shown that other Coronaviridae members that share similarities with SARS-CoV-2, like SARS-CoV, MERS-CoV and endemic human coronaviruses (HCoV) can stay afloat on plastic, metal and glass surfaces for up to 9 days (21). Moreover, the results of a very recent study have shown that SARS-CoV-2 can be viable up to 72 hours on plastic and stainless steel surfaces (20). Another recent study (22) has evaluated the stability of SARS-CoV-2 considering various factors such as temperature, different surface materials, and verified virucidal effects 
of common disinfectants. Their results have shown that the virus remains highly stable at $4^{\circ} \mathrm{C}$, but as the temperature is increased to $70^{\circ} \mathrm{C}$, the viability time decreases to 5 minutes. They have also figured out that SARS-CoV-2 can be stable on different surfaces such as printing and tissue papers ( 3 hours) wood and cloth (2 days), but more stable on smooth surfaces such as glass (4 days), stainless steel and plastic (7 days). The most concerning point was that the virus has been detected after 7 days on outer layer of laboratory infected surgical masks. They also examined the virucidal effects of various common disinfectants such as household bleach (1:49,1:99), hand soap solution (1:49), ethanol (70\%), povidone-iodine (7.5\%), chloroxylenol $(0.05 \%)$, chlorhexidine $(0.05 \%)$, and benzalkonium chloride $(0.1 \%)$ and determined that the infectious virus could not be detected after a 5-minute incubation at room temperature $\left(22^{\circ} \mathrm{C}\right)$ except for hand soap solution. In addition, they depicted that SARS-CoV-2 is particularly stable in broad-spectrum $\mathrm{pH}$ values ( $\mathrm{pH}: 3-10)$ at room temperature. They concluded that, although highly stable in a favorable environment, SARS-CoV-2 is susceptible to standard aforementioned disinfection methods (22). Therefore, since many surfaces involved in dental settings are made of these examined materials, if contaminated, they can be an impending source of infection in dental clinics where possible infectious droplets and aerosols are highly generated.

Another study (23) has shown that SARS-CoV and possibly MERS-CoV were found in samples taken from hospital surfaces at concentration far beyond of infective dose. So touching mouth, nose or eyes with prior contact with these surfaces could make individuals vulnerable for developing SARS or MERS (23). Thus, health care professionals especially dentists who have direct or indirect contact with patients' oral fluids, contaminated dental instruments or environmental surface are at a high risk of getting the COVID-19. In addition, close contact of patients' conjunctiva, nasal and oral mucosa with droplets and aerosols might do the same.

\section{Oral-fecal transmission}

While some published articles $(24,25)$ have supported the idea of oral-fecal transmission, this route of transmission has not been verified by $\mathrm{WHO}$, since there are no sufficient evidences (13). The study of Wu et al. (25), have shown that SARS-CoV-2 RNA can be detected in fecal samples of infected individuals 47 days after onset of first symptoms. Besides, SARS-CoV-2 could be found in fecal samples of some patients for a mean of 11.2 days even after respiratory tests became negative. Moreover, The study of Hindson (24) brought up the idea of digestive shedding of the virus which may lead to oral-fecal transmission. Nevertheless, proving this idea demands further studies.

\section{Protection and Prevention}

Since SARS-CoV-2 is abundantly present in patient's saliva, any dental procedure that has the ability to produce excessive amount of droplets and aerosols from saliva or even blood may cause airborne contamination (6). The latent period of COVID-19 is about three days, however, since infected people might be asymptomatic or be in incubation period (99\% 14 days) (26), it is almost impossible to make utmost prevention in dental clinics. Thus, according to different guidelines, all patients must be evaluated for possibility of infection with SARS-CoV-2; moreover, protective, preventive, and proactive measures must be adopted in order to avoid the transmission of SARS-CoV-2. Many authorities in different countries have proposed guidelines and guidance reports. Iran as a leading country fighting against corona virus has followed the guidelines of WHO and offered a dental guideline for COVID-19 pandemic available at (27) in Farsi language.

UK offered an official guidance issued mutually by the Department of Health and Social Care (DHSC), Public Health Wales (PHW), Public Health Agency (PHA) Northern Ireland, Health Protection Scotland (HPS), Public Health England (PHE) and NHS England (28). Their proposed guidance provides the infection prevention and control recommendations for health and social care workers who are involved with potential or confirmed COVID-19 patients.

ADA (29) has also proposed provisional recommendation and guidance resources for optimal protection against the risk of COVID-19 transmission as their primary infection control goal. CDC has stated that dental practice has distinctive features that necessitate additional infection control attentions. CDC's Interim Infection Prevention and Control Recommendations for patients with COVID-19 has been published with information that increments, but does not replace, the general infection prevention and control (IPC) recommendations for COVID-19 (30). In this guidance, CDC endorses a multi-step method, which concludes all preventive measures that should be regarded before and after arrival of the patient and during their presence under dental procedures (29). They have stated that dental health care personnel should adhere to standard precautions described as the minimum infection prevention practices in any health care setting that relates to patient care, regardless if the patient is suspected or confirmed to be infected (31).

\section{Patient evaluation}

This part is inevitably the first and most imperative part in preventive measures during the early stages of pandemic. Hierarchical figures of various guidelines illustrate most countries proposed different approaches to evaluate patients coming to dental clinics during the pandemic of SARSCoV-2. Nevertheless, they all agreed on using their questionnaire to screen a patient. The recommended guidelines until the date of this report are summarized in Figures 1 to 4.

\section{Hand hygiene}

Proper hand hygiene is an important protective measure for transmission of COVID-19, as it is for other infectious diseases. Having appropriate hand hygiene before examination and dental procedures, and after touching patient's oral cavity, secretion, blood, body fluids, and contaminated dental equipment is of ultimate importance (6). WHO has recommended 11-step hand hygiene technique with soap and water for duration of 40-60 seconds in the instance that hands are noticeably contaminated with blood or other body fluids. Moreover, WHO has suggested 8-step technique with alcohol-based hand rub for duration of 20-30 seconds to be appropriate (32). If there's no alcohol-based hand rub and soap accessible, then using $0.05 \%$ chlorinated water 


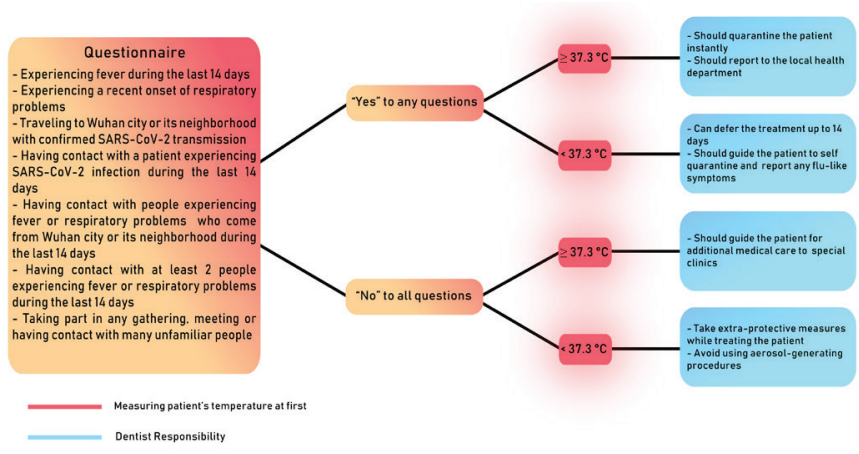

Figure 1. The summary of patient evaluation in dental clinics according to the 5th edition of the guideline for the diagnosis and treatment of novel coronavirus pneumonia drafted by the National Health Commission of the People's Republic of China (6).

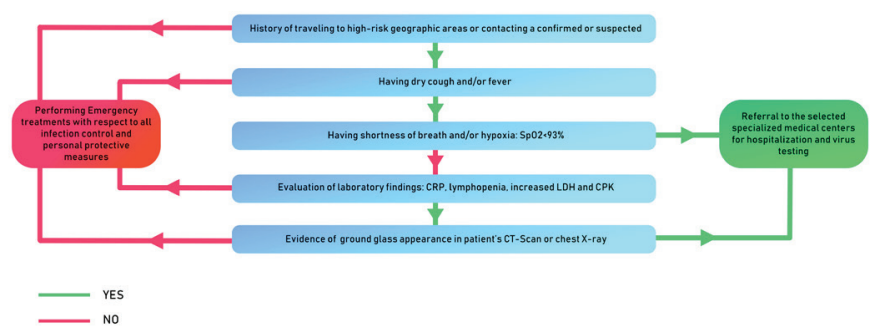

Figure 2. The summary of patient evaluation in dental clinics according to Iran's dental guideline for COVID-19 pandemic (27).

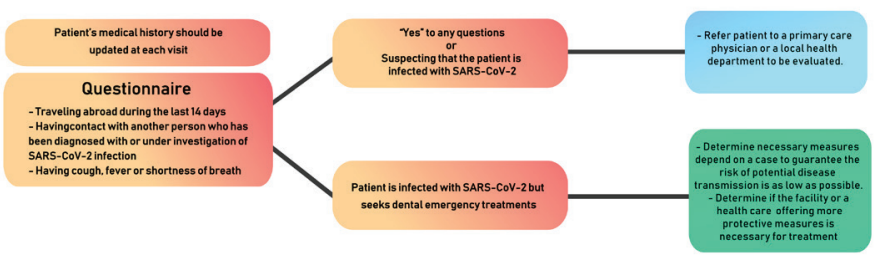

Figure 3. The summary of ADA interim guidance for screening patients in dental clinics (46).

for hand washing is an alternative; however, repeated use can lead to asthma and dermatitis that may subsequently increase the chance of infection (33). Also, WHO has suggested using solution comprised of ethanol (80\%), glycerol $(1.45 \%)$ and oxygen peroxide $(0.125 \%)$, or combination of isopropyl alcohol (75\%), glycerol (1.45\%) and oxygen peroxide $(0.125 \%)$ for hand disinfection (34).

\section{Disinfection}

SARS-CoV-2 can remain on contaminated surfaces, from a few hours up to several days, depending on the environment's temperature and humidity (20). Therefore, decontamination plays a significant role in preventing viral transmission, especially in healthcare facilities. Corona viruses are one of the easiest ones to be killed with disinfectants since they are enveloped viruses (21). According to a review of literature (21) on all available data for inactivation of coronaviruses family including SARS-CoV and MERS-CoV, various surface disinfectants have shown to be efficient. Nevertheless, the authors have concluded that only $0.1 \%$ sodium hypochlorite

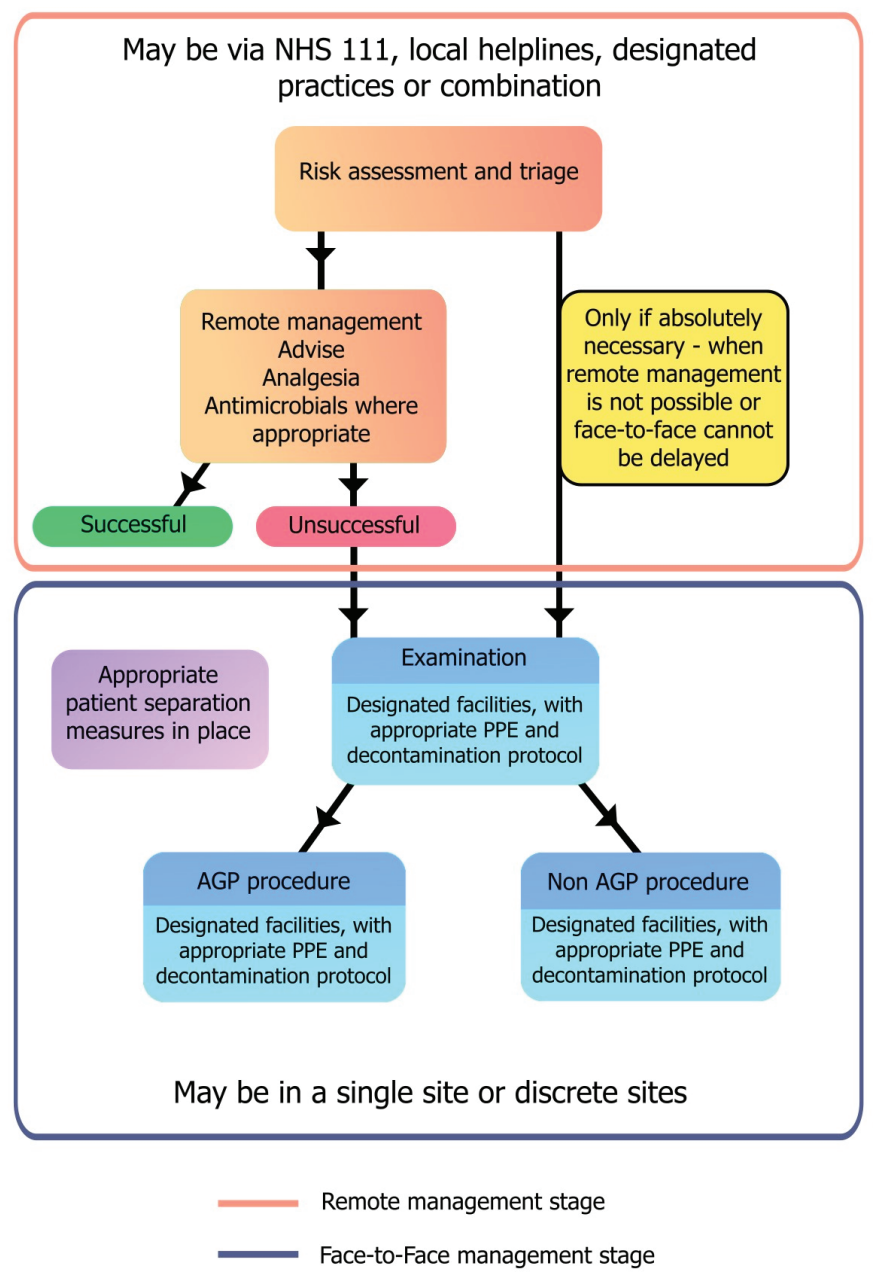

Figure 4. The summary of COVID-19 urgent dental care pathway according to NHS guideline. From: https://www.england.nhs. $u k /$ coronavirus/publication/covid-19-guidance-and-standardoperating-procedure-urgent-dental-care-systems-in-the-context-ofcoronavirus/. Site accessed April 15, 2020.

or $62-71 \%$ ethanol for 1 min on surfaces can meaningfully decrease coronavirus infectivity and they have expected the same outcome for SARS-CoV-2 infection. The WHO suggested thorough cleaning of environmental surfaces with detergent and employment of hospital level disinfectants such as $0.5 \%$ sodium hypochlorite (5000 ppm). This solution which can be prepared by dilution of 1-part home bleach ( $5 \%$ sodium hypochlorite) with 9 parts water (33) ensure an effective result of disinfecting surfaces (35). Furthermore, $70 \%$ ethanol was recommended for disinfecting small surfaces (33). For surface decontamination, ADA refers to disinfectant materials approved by the Environmental Protection Agency (EPA). The list of recommended EPA-approved products against SARSCoV-2 has been available for public (36). In addition, UK NHS has worked with PHE and assessed the available evidence and proposed the guidance for health professionals concerning UK's infection prevention and control recommendations for COVID-19 after some updates and revisions (37).

\section{Personal protective equipment (PPE)}

During the early phase of a pandemic, particularly when the vaccine is not introduced, personal protective equip- 
ment (PPE) plays a foremost role in controlling the disease (38). PPE comprises gloves, medical masks, goggles or a face shield, and gowns, and also respirators and aprons for particular instances. Respirators such as N95, Filtering Face piece Particles 2 (FFP2) or any equivalent standard), eye protection (goggles or face shield), long-sleeved gowns, gloves and also fluid-resistant aprons (if gowns are not waterproof) must be used to protect the health care workers including dentists during aerosol-generating procedures in pandemic of SARS-CoV-2 (39). Since SARS-CoV-2 is a virus with a diameter of $\sim 0.1 \mu \mathrm{m}$ (40) and N95 masks are able to filter $\approx 99.8 \%$ of particles with the same diameter size (41), these masks are capable of filtering free virions mostly (40). In addition, it seems that N95 masks are capable of protecting against large droplets $(>5 \mu \mathrm{m}$ in diameter) and droplet nuclei ( $\leq 5 \mu \mathrm{m}$ in diameter) which are formed by sneezing $(\sim 100 \mu \mathrm{m})$ and coughing $(\sim 1 \mu \mathrm{m})$.(40) However, during SARS-CoV outbreak in Toronto, using N95 masks by healthcare workers have decreased their mental performances and increased headaches among them (42). Considering all the facts, respirators like N95 mask or FFP2 or any equivalent standards are important parts of PPEs and are widely used even in short supply of PPE (39). WHO has recommended $\mathrm{N} 95$ usage for healthcare workers during SARS-CoV-2 pandemic especially when performing procedures that produce aerosols (39). In addition, WHO emphasizes to wear the mask appropriately; completely covering the mouth and nose and be tight to the face to minimize the gap between face and the mask. Once it is worn, it shouldn't be touched (43). Using one mask or respirator for more than 4 hours can cause discomfort and it should be avoided (39). Masks must be changed when they become damp. They must be removed from behind. Single-use masks must be discarded after each use and not be used again (43). WHO recommends cleaning utility gloves and discarding single-use gloves (nitrile or latex) after each use and forbids reusing them, moreover, hygiene should be accomplished after PPE is removed. It is suggested that leakage rates of both latex and nitrile gloves are almost similar to one another. Whereas, vinyl gloves have more defects compared to latex ones, especially after use (32). Different studies have shown that latex gloves are stronger barriers against virus penetration than vinyl or polyethylene $(44,45)$. Even in exposure to $70 \%$ ethanol which is frequently used for disinfection, latex gloves still remain good barriers in spite of having $1 \%$ penetration (44). Figures 5-6 and Table 1 portray the PPE recommended by different authorities and guidelines.

\section{Mouthwash}

As SARS-CoV-2 is susceptible to oxidation, ADA has recommended $1 \%$ hydrogen peroxide mouthwash before appointment in order to decrease salivary load of oral microbes including SARS-CoV-2 (46). Moreover, chlorhexidine (CHX) has been shown to have antibacterial, antifungal and also antiviral activity against some lipid-enveloped viruses (47). As SARS-CoV-2 is a lipid-enveloped virus, it could be sensitive to this solution. However, in a brief review of literature by Harrel et al. (48), it was mentioned that $\mathrm{CHX}$ is unlikely to affect neither the blood coming directly from the operat-

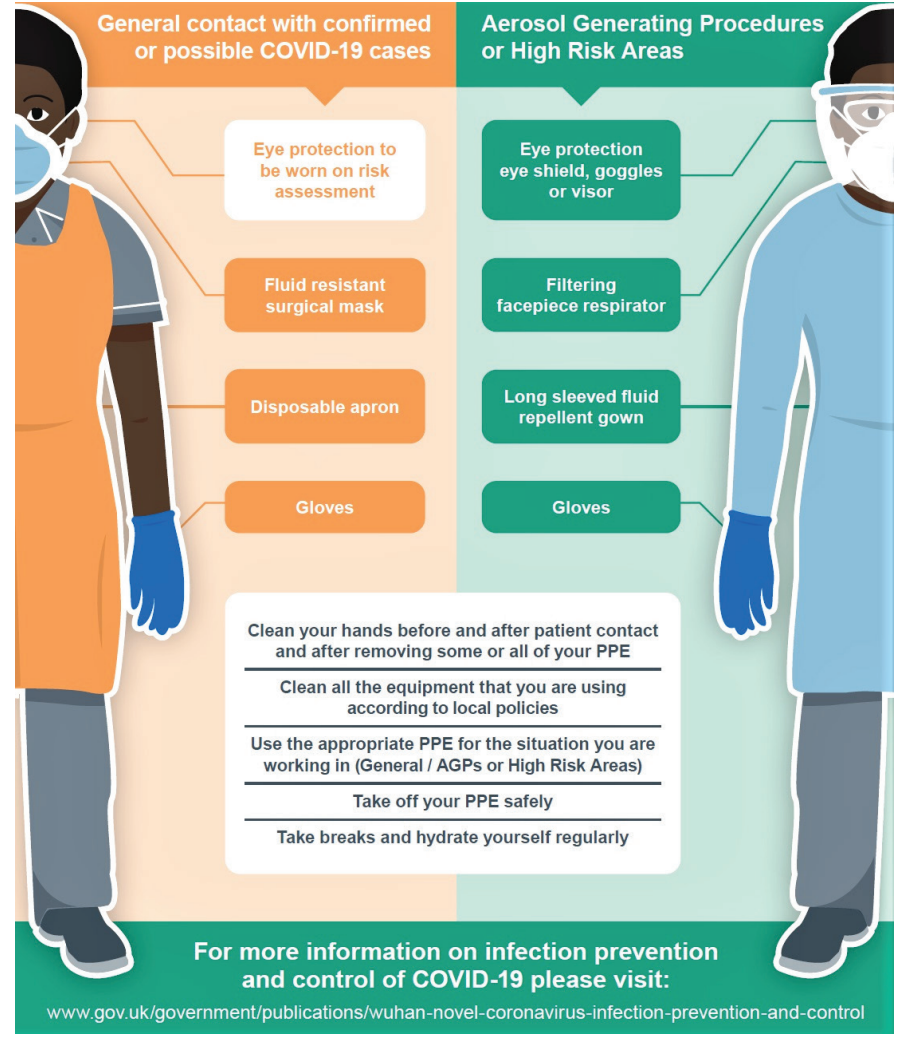

Figure 5. Visual guide to safe PPE according to guidance on infection prevention and control for COVID-19 by PHE. From: https://assets. publishing.service.gov.uk/government/uploads/system/uploads/ attachment_data/file/878056/PHE_COVID-19_visual_guide_poster_ PPE.pdf. Site accessed April 24, 2020.
A)

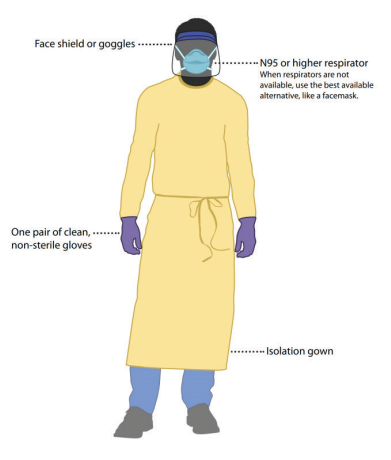

B)

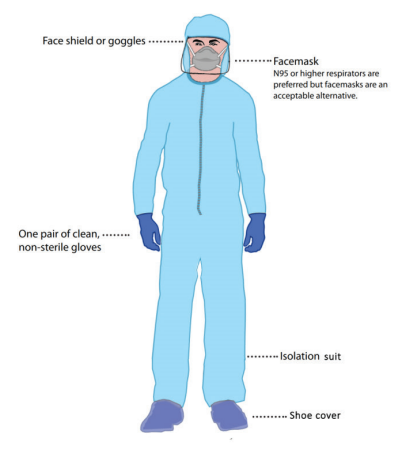

Figure 6. A schematic figure of PPE for dental procedures during outbreak recommended by current guidelines. From: https://Www. cdc.gov/coronavirus/2019-ncov/downloads/COVID-19_PPE_ illustrations-p.pdf. Site accessed April 3, 2020.

ing site nor the nasopharynx-harbored viruses and bacteria. According to available literature, povidone-iodine mouthwash was verified to be the only sufficient mouthwash for pre-procedural rinsing in dental practice against Coronaviridae family. Whereas, CHX was shown to be ineffective against coronaviruses (49). The study reported by Peng et al. (6) recommends the use of oxidative agents against SARS$\mathrm{CoV}-2$. Hence, mouthwashes containing $1 \%$ hydrogen peroxide or $0.2 \%$ povidone can be regarded feasible in elimination or reducing the load of SARS-CoV-2 in saliva. Moreover, mouthwashes are intensely advocated in dental procedures where the rubber dam is not, or could not be used (50). 
Table 1.PPE for urgent dental procedures recommended by NHS. 1- Fluid-resistant gowns (or long-sleeved waterproof apron) must be worn during aerosol generating procedures (AGPs). If non-fluid-resistant gowns are used, a disposable plastic apron should be worn underneath. 2-If wearing an FFP3 that is not fluid-resistant, a full-face shield/visor must be worn. 3-Eye protection should be discarded after each use. Otherwise, if polycarbonate safety glasses/goggles or any equivalent are used, they should be disinfected according to manufacturers' guidance. Available at: https://www.england.nhs.uk/coronavirus/publication/covid-19-guidance-and-standard-operating-procedure-urgent-dental-care-systems-inthe-context-of-coronavirus/. Site accessed April 15, 2020

Personal protective equipment (PPE) for COVID-19 urgent dental care settings

\begin{tabular}{lccc}
\hline & $\begin{array}{c}\text { Waiting room/reception } \\
\text { No clinical treatment }\end{array}$ & $\begin{array}{c}\text { Dental surgery } \\
\text { Non AGP treatment }\end{array}$ & $\begin{array}{c}\text { Dental surgery } \\
\text { Treatments involving AGPs }\end{array}$ \\
\hline Good hand hygiene & $\sqrt{ }$ & $\sqrt{ }$ & $\sqrt{ }$ \\
\hline Disposable gloves & $\mathrm{X}$ & $\sqrt{ }$ & $\mathrm{V}$ \\
\hline Disposable plastic aparon & $\mathrm{X}$ & $\mathrm{X}$ & $\sqrt{(1)}$ \\
\hline Disposable gown (1) & $\mathrm{X}$ & $\sqrt{ }$ & $\mathrm{X}$ \\
\hline Fluid-resistant surgical mask & $\sqrt{ }$ & $\mathrm{X}$ & $\sqrt{ }$ \\
\hline $\begin{array}{l}\text { Filtering piece (FFP3) } \\
\text { respirator (2) }\end{array}$ & $\mathrm{X}$ & $\mathrm{V}$ & $\sqrt{ }$ \\
\hline \begin{tabular}{l} 
Eye protection (3) \\
\hline
\end{tabular}
\end{tabular}

With all these debates on, further studies are required to prove which mouthwash is more efficient against SARS-CoV-2.

\section{Protective measures in dental procedures}

As SARS-CoV-2 might be transmitted via aerosol, using aerosol-generating instruments and performing such procedures including ultrasonic and sonic scalers, air polishing, air-water syringe, tooth preparation with turbine handpiece or air abrasion should be minimized as much as possible $(26,48)$. While using PPE during aerosol-generating procedures is prerequisite, WHO has recommended to perform these dental procedures in a room with minimum ventilation rate of $160 \mathrm{~L} / \mathrm{s}$ per patient or in negative-pressure rooms with minimum 12 air changes per hour and regulated air flow direction when mechanical ventilation is used. Furthermore, individuals presenting in the room should be as minimum as required for patient treatment (35).

Two methods are available to decrease airborne contamination produced from the treatment site before and after it becomes airborne. Practically, it is easiest to eliminate as much airborne contamination as possible before it outflows from the proximate of operational and treatment region (48). One method is to remove the airborne contamination before it escapes from the most closed area surrounding the operational site. The employment of a high-volume evacuator (HVE) has been proved to reduce the contamination occurring from the operative site by more than $90 \%$ (48). It has been proved that the number of colony-forming units, produced during dental procedures is decreased greatly when an assistant uses an HVE. The usual HVE used in dentistry has a large opening (usually $\geq 8$ millimeters) and is joined to an evacuation system that removes a large air volume (100 cubic feet / minute). A typical saliva ejector in the dental units cannot be categorized as an HVE because of its small opening that does not remove sufficient large volume of air (48). The other method includes employing devices that eliminate the contaminated material from the air of the operational area after it has become airborne. The most fre- quently methods are the use of a high efficiency particulate air (HEPA) filter and the use of ultraviolet (UV) chambers in the ventilation system. While both of these systems are effective, they are almost expensive (48).

Rubber dams and HVEs reduce aerosol or spatter in dental procedures. Using rubber dams can greatly decrease the development of saliva- and blood-contaminated aerosols or spatters, particularly when high-speed handpieces and ultrasonic dental devices are used (6). It was reported that the use of rubber dam could significantly reduce airborne particles by $70 \%$ in the operating field's 3-foot diameter (6). When rubber dam is implemented, extra HVE for aerosol and spatter together with usual unit suction should be used during the operations. In this case, it is also important to adopt a full four-hand operation (6). Although in some cases isolation of the rubber dam is not feasible, manual tools such as Carisolv and hand scaler are advised for caries removal and periodontal scaling to reduce aerosol generation as much as possible (6). Moreover, Extra-oral evacuation devices and special aerosol reduction devices deliberated to use with ultrasonic scalers are also regarded to reduce droplets and aerosols generated during scaling procedures (51).

In addition to the above precautions, controlling patient's gag, cough and vomit reflex in dental clinics can minimize droplet and aerosol production (51). Several strategies for avoiding gagging are proposed in literature, including behavioural modifications as well as pharmacological and non-pharmacological management. Behavioural modification techniques include relaxing, distraction, suggestion/ hypnosis, and so on. Pharmacological techniques such as using topical and local anaesthetics as well as antihistamines, sedatives, CNS depressants and so on could be used to manage gag reflex. Using salt on the anterior part of the tongue as a suitable non-pharmacological remedy could have the same effect as well (52).

In dental procedures, the high-speed dental handpiece without anti-retraction valves might aspire and eject the debris and fluids. Most specifically, the pathogens, including 
bacteria and viruses, can also contaminate the air and water tubes in the dental device, which can thus possibly cause cross-infection (6). In a review study, using anti-retraction high-speed handpieces was recommended during this pandemic period of COVID-19 in order to potentially prevent cross-contamination (6). This research has shown that the high-speed dental anti-retraction handpiece can substantially reduce the backflow of oral bacteria and HBV into the handpiece and dental unit tubes as opposed to the handpiece without anti-retraction feature (6).

On the other hand, it is reported that microbes might be present in the smoke and particulate debris (plume) produced during laser and electrosurgery treatments (51). Garden et al. (53) have shown that laser plume can contain and transmit papillomavirus DNA. Although those findings cannot be generalized to SARS-CoV-2, cautions should be taken when using such devices.

\section{Radiological examination}

Intraoral radiography remains the most popular x-ray technique used in dental imaging; however, the use of this technique should be replaced with extraoral radiographies such as panoramic radiography or cone beam computed tomography $(\mathrm{CBC})$, since the intra oral radiographies can induce saliva secretion, gag reflex and coughing $(26,51)$. Otherwise, when intraoral radiographies are required, barriers should be used twice on sensors to avoid perforation and cross contamination (54). During dental radiology procedures, precautions taken to prevent nosocomial human-to-human transmission may play a substantial role in decreasing the spread of COVID-19. All relevant protective approaches should be adopted to reduce the risk of infection among staff and patients.

\section{Proper management of medical and dental waste}

Policies and procedures for the effective management of health-care waste should be followed, including determining authority and sufficient human and material assets for safe disposal of such waste. There is no proof that direct, unsafe human contact has contributed in the transmission of the COVID-19 virus during the management of the health care waste $(33,55)$.

Any medical waste generated during treatment of COVID-19 patient should be carefully deposited in specified containers and appropriate bags, and then safely discarded, preferably on location. All those who handle medical waste should use PPE such as eye protection, mask, longedsleeved gown, thick gloves, apron, and boots. After removal, hand hygiene should be performed $(33,55)$.

\section{COVID-19 diagnostic test for dental health care professionals}

The significance of COVID-19 diagnostic test for dentists and dental team is unequivocal. This should be performed in hospitals with the same high priority as that of medical healthcare professionals. One should not underestimate the possibility of a dental practitioner being positive for COVID-19 and potentially infecting patients attending emergency dental services (38).

\section{Conclusion}

Saliva might have a critical role in direct and indirect transmission of COVID-19. Because of the infectious potential of saliva in transmission of COVID-19, it is essential to develop effectual policies for prevention and protection during aerosol-generating dental procedures especially for dental team and patients. These strategies include accurate perception of the transmission routes, training and testing dental staff for COVID-19, submitting proper protective and preventive measures, accurate patient evaluation, hand hygiene, employing adequate disinfection method of dental settings and office, using recommended personal protective equipment, and finally proper discarding wastes. Saliva can also be used for diagnostic methods, which are non-invasive, convenient, and cost-prohibited and may deliver fast and early detection of COVID-19.

Türkçe Özet: Bulaşmada diş hekimliği uygulamalarında tükürüğün rolüne ilişkin COVID-19 ikilemi: güncel kanıtların kısa bir incelemesi. Yeni bir $\beta$-coronavirus (2019-nCoV) neden olduğu akut bir solunum sistemi sendromu salgını olan insan yeni coronavirus hastalığı (COVID-19) 12 Aralık 2019'dan itibaren kişiden kişiye bulaşma yoluyla küresel olarak yayılmaya başlamıştır. Diş hekimliği prosedürlerinin ürettiği aerosol sırasında oluşan havadaki uçuşan materyaller yüz yüze iletişim, sıçramış tükürük, kan ve diğer vücut sıvılarıyla aracılığıyla diş hekimliği ekibini ve hastalarını belirgin bulaşma riskine maruz bırakacaktır. Diş hekimleri, COVID-19 bulaşmasının önlenmesinde önemli yardımları olabilir. Bu çalışma, tükürük rolünü ve diş hekimliği prosedürleri sırasında hastalığın bulaşmasında doğabilecek tehditleri ele alan literatürdeki güncel kanıtları incelemiştir. Bu çalışma ayrıca, salgın sırasında diş hekimliği uygulamaları için olası kişiden kişiye veya diş hekimliği ortamında dolaylı bulaşmayı engellemek için uygulanabilir proaktif ve önleyici tedbirleri önermektedir. Anahtar Kelimeler: SARS-CoV-2, COVID-19, Tükürük, Bulaşma, Infeksiyon Kontrolü

Acknowledgment: The authors would like to thank Mr. Hirad Babayan (B.SC. CS) for his invaluable assistance in creating the figures.

Ethics Committee Approval: Not required.

Informed Consent: Not required.

Peer-review: Externally peer-reviewed.

Author contributions: $\mathrm{SH}$ and NF designed the study. $\mathrm{SH}, \mathrm{NF}, \mathrm{AZ}$ and $\mathrm{HP}$ participated in gathering the data for the study. $\mathrm{SH}, \mathrm{NF}, \mathrm{AZ}$ and HP wrote the majority of the original draft of the paper. $\mathrm{SH}, \mathrm{NF}$, AZ and HP participated in writing the paper. All authors approved the final version of this paper.

Conflict of Interest: The authors had no conflict of interest to declare.

Financial Disclosure: The authors declared that this study has received no financial support.

\section{References}

1. Zhu N, Zhang D, Wang W, Li X, Yang B, Song J, et al. A novel coronavirus from patients with pneumonia in China, 2019. N Engl J Med. 2020. [CrossRef]

2. Lu R, Zhao X, Li J, Niu P, Yang B, Wu H, et al. Genomic characterisation and epidemiology of 2019 novel coronavirus: implications for virus origins and receptor binding. Lancet. 2020;395(10224):565-74. [CrossRef] 
3. Huang C, Wang Y, Li X, Ren L, Zhao J, Hu Y, et al. Clinical features of patients infected with 2019 novel coronavirus in Wuhan, China. Lancet. 2020. [CrossRef]

4. Zhou P, Yang X-L, Wang X-G, Hu B, Zhang L, Zhang W, et al. A pneumonia outbreak associated with a new coronavirus of probable bat origin. Nature. 2020.

5. Sabino-Silva R, Jardim ACG, Siqueira WL. Coronavirus COVID-19 impacts to dentistry and potential salivary diagnosis. Clin Oral Investig [Internet]. 2020;13-5. [CrossRef]

6. Peng $X, X u X, L i$, Cheng $L$, Zhou X, Ren B. Transmission routes of 2019-nCoV and controls in dental practice. Int J Oral Sci [Internet]. 2020;(February):1-6. [CrossRef]

7. Spagnuolo G, Vito D De, Rengo S, Tatullo M. COVID-19 Outbreak: An Overview on Dentistry. Int J Environ Res Public Heal 2020, Vol 17, Page 2094. 2020. [CrossRef]

8. World Health Organization(WHO). Q\&A on coronaviruses (COVID-19) [Internet]. 2020. Available from: https://www.who. int/news-room/q-a-detail/q-a-coronaviruses

9. To KK-W, Tsang OT-Y, Chik-Yan Yip C, Chan K-H, Wu T-C, Chan JMC, et al. Consistent detection of 2019 novel coronavirus in saliva. Clin Infect Dis. 2020. [CrossRef]

10. Spicciarelli V, Marruganti C, Viviano M, Baldini N, Franciosi G, Tortoriello $\mathrm{M}$, et al. Prevention and safety in the dental office after Novel Human Coronavirus outbreak: unresolved questions and future directions. J Osseointegration. 2020;155-63.

11. Khurshid Z, Asiri FYI, Al Wadaani H. Human saliva: non-invasive fluid for detecting Novel Coronavirus (2019-nCoV). Int J Environ Res Public Health. 2020;17(7):2225. [CrossRef]

12. Farshidfar $\mathrm{N}$, Hamedani S. Hyposalivation as a potential risk for SARS-CoV-2 infection: Inhibitory role of saliva. Oral Dis [Internet]. 2020 Apr 29;n/a(n/a). [CrossRef]

13. World Health Organization(WHO). Modes of transmission of virus causing COVID-19: implications for IPC precaution recommendations. 2020;(March):1-3. [CrossRef]

14. Wax RS, Christian MD. Practical recommendations for critical care and anesthesiology teams caring for novel coronavirus (2019-nCoV) patients. Canadian Journal of Anesthesia. 2020. [CrossRef]

15. Xu H, Zhong L, Deng J, Peng J, Dan H, Zeng X, et al. High expression of ACE2 receptor of 2019-nCoV on the epithelial cells of oral mucosa. Int J Oral Sci. 2020. [CrossRef]

16. Liu L, Wei Q, Alvarez X, Wang H, Du Y, Zhu H, et al. Epithelial Cells Lining Salivary Gland Ducts Are Early Target Cells of Severe Acute Respiratory Syndrome Coronavirus Infection in the Upper Respiratory Tracts of Rhesus Macaques. J Virol. 2011. [CrossRef]

17. Gralton J, Tovey ER, Mclaws ML, Rawlinson WD. Respiratory virus RNA is detectable in airborne and droplet particles. J Med Virol. 2013. [CrossRef]

18. Bai $Y$, Yao L, Wei T, Tian F, Jin D-Y, Chen L, et al. Presumed Asymptomatic Carrier Transmission of COVID-19. JAMA. 2020. [CrossRef]

19. Rothe C, Schunk M, Sothmann P, Bretzel G, Froeschl G, Wallrauch C, et al. Transmission of 2019-nCoV Infection from an Asymptomatic Contact in Germany. N Engl J Med. 2020. [CrossRef]

20. Doremalen N van, Bushmaker T, Morris D, Holbrook M, Gamble A, Williamson B, et al. Aerosol and surface stability of HCoV19 (SARS-CoV-2) compared to SARS-CoV-1. medRxiv. 2020. [CrossRef]

21. Kampf G, Todt D, Pfaender S, Steinmann E. Persistence of coronaviruses on inanimate surfaces and their inactivation with biocidal agents. Journal of Hospital Infection. 2020. [CrossRef]

22. Chin A, Chu J, Perera M, Hui K, Yen H-L, Chan M, et al. Stability of SARS-CoV-2 in different environmental conditions. medRxiv. 2020. [CrossRef]

23. J.A. O, C. D, S. Y, S. D, S.D. G, D.J. W. Transmission of SARS and MERS coronaviruses and influenza virus in healthcare settings: The possible role of dry surface contamination. J Hosp Infect. 2015.
24. Hindson J. COVID-19: faecal-oral transmission? Nat Rev Gastroenterol Hepatol [Internet]. 2020. [CrossRef]

25. Wu Y, Guo C, Tang L, Hong Z, Zhou J, Dong X, et al. Prolonged presence of SARS-CoV-2 viral RNA in faecal samples. Lancet Gastroenterol Hepatol. 2020. [CrossRef]

26. Meng L, Hua F, Bian Z. Coronavirus Disease 2019 ( COVID-19): Emerging and Future Challenges for Dental and Oral Medicine. 2020;2019. [CrossRef]

27. Medical Council of the Islamic Republic of Iran. Iran's dental guideline for COVID-19 pandemic [Internet]. 2020. [CrossRef]

28. Public Health England. COVID-19: infection prevention and control (IPC) [Internet]. 2020. [CrossRef]

29. American Dental Association (ADA). ADA Interim Guidance for Minimizing Risk of COVID-19 Transmission [Internet]. 2020. [CrossRef]

30. Centers for Disease Control and Prevention (CDC). Interim Infection Prevention and Control Recommendations for Patients with Suspected or Confirmed Coronavirus Disease 2019 (COVID-19) in Healthcare Settings [Internet]. 2020. [CrossRef]

31. Centers for Disease Control and Prevention (CDC). Interim Infection Prevention and Control Guidance for Dental Settings During the COVID-19 Response [Internet]. 2020. [CrossRef]

32. Pittet D, Allegranzi B, Boyce J, Experts WHOWA for PSFGPSCCG of. The World Health Organization guidelines on hand hygiene in health care and their consensus recommendations. Infect Control Hosp Epidemiol. 2009;30(7):611-22. [CrossRef]

33. World Health Organization(WHO). Water, sanitation, hygiene and waste management for the COVID-19 virus. 2020;(March):1-6. [CrossRef]

34. World Health Organization(WHO). Guide To Local Production: Who-Recommended Handrub Formulations. 2015;(April):1-9. [CrossRef]

35. World Health Organization(WHO). Infection prevention and control during health care when novel coronavirus (nCoV) infection is suspected. 2020;(March):1-5. [CrossRef]

36. United States Environmental Protection Agency. List $\mathrm{N}$ : Disinfectants for Use Against SARS-CoV-2 [Internet]. 2020. [CrossRef]

37. Public Health England and Department of Health and Social Care. COVID-19: guidance for health professionals [Internet]. 2020. Available from: https://www.gov.uk/government/ collections/wuhan-novel-coronavirus\#guidance

38. Dave M, Seoudi N, Coulthard P. Urgent dental care for patients during the COVID-19 pandemic. Lancet. 2020. [CrossRef]

39. World Health Organization(WHO). Rational use of personal protective equipment (PPE) for coronavirus disease (COVID-19). 2020;(March):1-7. [CrossRef]

40. Bar-On YM, Flamholz A, Phillips R, Milo R. SARS-CoV-2 (COVID-19) by the numbers. Elife. 2020 Mar; 9. [CrossRef]

41. Rengasamy S, Shaffer R, Williams B, Smit S. A comparison of facemask and respirator filtration test methods. J Occup Environ Hyg. 2017. [CrossRef]

42. Chung SJ, Ling ML, Seto WH, Ang BS, Tambyah PA. Debate on MERS-CoV respiratory precautions: surgical mask or N95 respirators? Singapore Med J [Internet]. 2014 Jun;55(6):294-7. [CrossRef]

43. World Health Organization(WHO). Advice on the use of masks in the community, during home care, and in health care settings in the context of COVID-19. 2020;(March):1-2. [CrossRef]

44. Klein RC, Party E, Gershey EL. Virus penetration of examination gloves. Biotechniques [Internet]. 1990 Aug;9(2):196-199. [CrossRef]

45. Korniewicz DM, Laughon BE, Cyr WH, Lytle CD, Larson E. Leakage of virus through used vinyl and latex examination gloves. J Clin Microbiol. 1990;28(4):787-8. [CrossRef]

46. American Dental Association. Coronavirus Frequently Asked Questions [Internet]. 2020. [CrossRef]

47. Bouadma L, Karpanen T, Elliott T. Chlorhexidine use in adult patients on ICU. Intensive Care Med [Internet].2018;44(12):2232-4. [CrossRef] 
48. Harrel SK, Molinari J. Aerosols and splatter in dentistry: A brief review of the literature and infection control implications. J Am Dent Assoc. 2004. [CrossRef]

49. Farzan A, Firoozi P. Which Mouthwashe is Appropriate for Eliminating Coronaviruses? A.

50. Izzetti R, Nisi M, Gabriele M, Graziani F. COVID-19 Transmission in Dental Practice: Brief Review of Preventive Measures in Italy. J Dent Res. 2020;0022034520920580. [CrossRef]

51. Li RWK, Leung KWC, Sun FCS, Samaranayake LP. Severe acute respiratory syndrome (SARS) and the GDP. Part II: Implications for GDPs. Br Dent J. 2004;197(3):130-4. [CrossRef]

52. Prashanti E, Sumanth KN, George PR, Karanth L, Soe HHK. Management of gag reflex for patients undergoing dental treatment. Cochrane Database Syst Rev. 2015;(10). [CrossRef]
53. Garden JM, O'Banion MK, Bakus AD, Olson C. Viral disease transmitted by laser-generated plume (aerosol). Arch Dermatol. 2002;138(10):1303-7. [CrossRef]

54. Ather A, Patel B, Ruparel NB, Diogenes A, Hargreaves KM. Coronavirus Disease 19 (COVID-19): Implications for clinical dental care. J Endod. 2020. [CrossRef]

55. World Health Organization(WHO). Safe management of wastes from health-care activities: a summary [Internet]. Geneva PP Geneva: World Health Organization; 2017. [CrossRef] 